\title{
ACUTE TOXICITY OF CARBAMATE-BASED PESTICIDES FOR FISH
}

\author{
J. HEJDUK, Z. SVOBODOVÁ
}

University of Agriculture, Ceské Budějovice and Fisheries Research Institute, 38925 Vodňany

Received April 4, 1979

\begin{abstract}
Hejduk J., Z. Svobodová: Acute Toxicity of Carbamate-based Pesticides for Fish. Acta vet. Brno, 49, 1980: 251-257.

Ichthyotoxicological examination of carbamate-based pesticides was made according to the norm CSN 466807 "Test of Acute Toxicity for Fish". The following compounds were tested: Novozir MN 80, Elocron WP 50, Furadan 5-G and Fundazol. On the basis of the determined $\mathrm{LC}_{50}$ values all compounds have been included among substances highly toxic for fish in the following order: Furadan G-5 > $>$ Novozir MN 80> Elocron WP $50>$ Fundazol. The most susceptible fish species was found to be the rainbow trout followed by Poecilia reticulata and carp. The clinical signs and pathoanatomical lesions of the intoxication with carbamatebased pesticides in fish were not specific.
\end{abstract}

Acute toxicity, $L C_{50}$, Cyprinus carpio L., Salmo gairdneri Rich., Poecilia reticulata.

The increasing chemization in all areas of man's activities has besides its benefits also a negative impact. At present, all newly introduced chemical compounds must be evaluated and tested for all possible effects. This pertains particularly to pesticides whose testing must include also the ichthyopathological examination in areas of their use as indicated by the protocols gathered at the Fisheries Research Institute in Vodñany showing high incidence of fish intoxications by pesticides ( $\mathrm{S}$ vobodová and Kocová 1973).

The present work is focused at the carbamate-based pesticides which are being increasingly employed as herbicides, fungicides, insecticides and acaricides.

\section{Materials and Methods}

The following carbamate-based pesticides were examined for their toxicity for fish: Novozir MN 80, Elocron WP 50, Furadan G-5 and Fundazol. The acute toxicity of these compounds. was determined according to the CSN 466807 "Test of Acute Toxicity for Fish". Data on the tested pesticides were obtained from the list of permitted preparations for plant protection. The experimental fish were in good state of health. During the preliminary trial the clinical and pathoanatomical signs of intoxication were observed.

\section{Novozir MN 80}

is a yellow-brown pulver a characteristic odour. In water it forms a very good suspension. The active substance is $80 \%$ mancozeb (zinc manganate etylen-bis-dithiocarbamidan). For the toxicity test, carp (Cyprinus carpio L.) weighing $5.78 \mathrm{~g}(5.4-6.5 \mathrm{~g}$ ), with body length of $5.38 \mathrm{~cm}$ $(4.2-7.3 \mathrm{~cm})$ and average Fulton's coefficient of $2.96(2.55-3.91)$ were used. Further, rainbow trout (Salmo gairdneri Rich.) fry weighing $2.88(1.4-4.8 \mathrm{~g}$ ), with average body length of $5.74 \mathrm{~cm}$ $(4.6-7.3 \mathrm{~cm})$ and Fulton's coefficient of $1.49(1.13-1.74)$ and specimens of Poecilia reticulata $2.19 \mathrm{~cm}(1.7-3.0 \mathrm{~cm})$ long and not older than 6 months were used.

Elocron WP 50

is a grayish-white pulver with the active substance $50 \%$ dioxacarb (2-(1,3-dioxolane-2-yl)-phenyl$-\mathrm{N}$-methylcarbamate). For testing, carp weighing $9.38 \mathrm{~g}(6.6-14.7 \mathrm{~g})$ and $6.49 \mathrm{~cm}(5.4-7.6 \mathrm{~cm})$ long were used. Their Fulton's coefficient was $3.39(3.16-3.75)$. The rainbow trout weighing 
$2.45 \mathrm{~g}(1.12-5.1 \mathrm{~g})$ and $5.4 \mathrm{~cm}(4.2-7.0 \mathrm{~cm})$ long with Fulton's coefficient averaging $1.35(1.15$ to 1.48) and Poecilia reticulata specimens $2,29 \mathrm{~cm}$ long $(1.7-3.1 \mathrm{~cm})$ and no older than 6 months were used.

\section{Furadan G-5}

is distributed in green-blue granules up to $1 \mathrm{~mm}$ in size. The active substance is $5 \%$ carbofurane (2,3-dihydro-2,2-dimethyl-7-benzofuranyl methylcarbamate).

For testing, carp weighing $8.1 \mathrm{~g}(6.1-11.0 \mathrm{~g})$ and $6.24 \mathrm{~cm}(5.7-7.0 \mathrm{~cm})$ long were used. Their Fulton's coefficient averaged $3.28(2.99-3.56)$. The rainbow trout weighing $3.31 \mathrm{~g}(1.8-3.8 \mathrm{~g})$, $6.22 \mathrm{~cm}(5.0-6.9 \mathrm{~cm})$ long with Fulton's coefficient averaging $1.34(1.27-1.48)$, and the Poecilia reticulata specimens $2.08 \mathrm{~cm}(1.7-2.5 \mathrm{~cm})$ long and aged up to 6 months were used.

Fundazol

is a greyish-white pulverized compound used in spray form. The active substance is $50 \%$ benzomyle (1-(N-butylcarbamoyl)-2-(methoxy-carboxamido)-benzimidazole).

For testing, carp weighing $7.74 \mathrm{~g}(5.2-10.5 \mathrm{~g})$ and $6.15 \mathrm{~cm}$ long $(5.6-6.8 \mathrm{~cm})$, with Fulton's coefficient averaging $3.27(2.86-3.62)$. The rainbow trout were weighing $2.87 \mathrm{~g}(1.9-5.7 \mathrm{~g})$, they were $5.76 \mathrm{~cm}$ long $(4.0-7.7 \mathrm{~cm})$ and their Fulton's coefficient averaged $1.37(1.08-1.55)$. The Poecilia reticulata specimens were $2.77 \mathrm{~cm}(2.2-3.4 \mathrm{~cm})$ long and aged up to 6 months.

\section{Results}

\section{Novozir MN 80}

Toxicity for fish: In the 48-hour interval, the $\mathrm{LC}_{j 0}$ of Novozir MN 80 was $24.0 \mathrm{mg} .1^{-1}$ for the carp, $1.85 \mathrm{mg} .1^{-1}$ for the rainbow trout, and $2.2 \mathrm{mg} .1^{-1}$ for Poecilia reticulata. The minimum lethal concentration $\left(\mathrm{LC}_{5}\right)$ was $15 \mathrm{mg} .1^{-1}$ for the carp, $1.0 \mathrm{mg} .1^{-1}$ for the rainbow trout and $0.9 \mathrm{mg} .1^{-1}$ for Poecilia reticulata in the same interval. From the time course of lethal intoxication with Novozir MN 80, given in Fig. 1, high toxicity for fish is obvious.

Clinical findings: In all fish species exposed to the toxic substance restless movements in the upper half of the aquarium were observed. Increased respiration, occasionally even convulsions of the mouth and opercles were noted. After this relatively long period first signs of lost balance occurred, later progressive increase of uncoordinated movements was evident with turning along the body

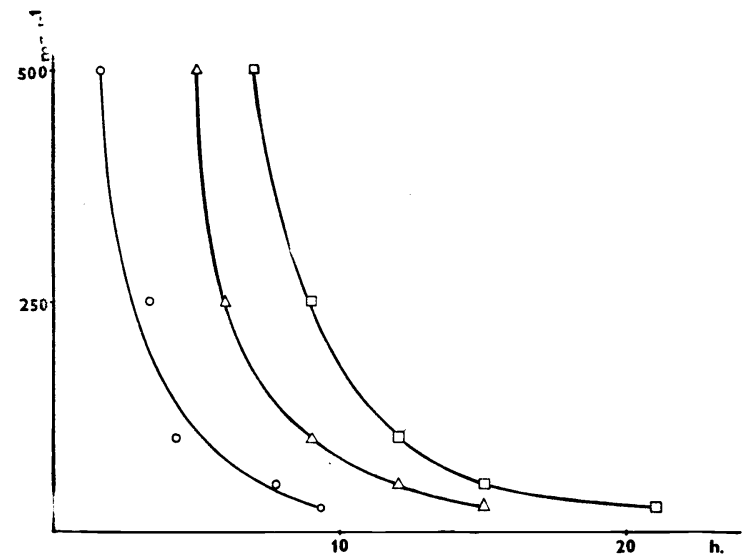

Fig. 1: Course of lethal intoxication by Novozir MN 80 axis. Before death, excitation with jumping above the water surface and swimming on one side was observed.

Pathoanatomical findings: The body surface of affected fish was polluted with the preparation. Skin slightly more mucous and pale. Eyes unchanged. The gills with smooth margins and increased mucous discharge, polluted with the preparation in fish exposed to its high concentrations. The lower parts of the gills were slightly more mucous. In the body cavity injected hepatic and hepatopancreatic blood vessels were found. 


\section{Elocron WP 50}

Toxicity for fish: The $\mathrm{LC}_{50}$ of this compound was $25.5 \mathrm{mg} . \mathrm{1}^{-1}$ for the carp, $2.7 \mathrm{mg} .1^{-1}$ for the rainbow trout, and $36.0 \mathrm{mg} .1^{-1}$ for Poecilia reticulata in 48 hours. The minimum lethal concentration $\left(\mathrm{LC}_{5}\right)$ was found to be $17.5 \mathrm{mg} .1^{-1}$ for the carp, $0.35 \mathrm{mg} .1^{-1}$ for the rainbow trout and $16.0 \mathrm{mg} .1^{-1}$ for Poecilia reticulata in the same interval. The relation between the average survival time and the concentration of Elocron WP 50 is given in Fig. 2. The preparation is highly toxic for fish.

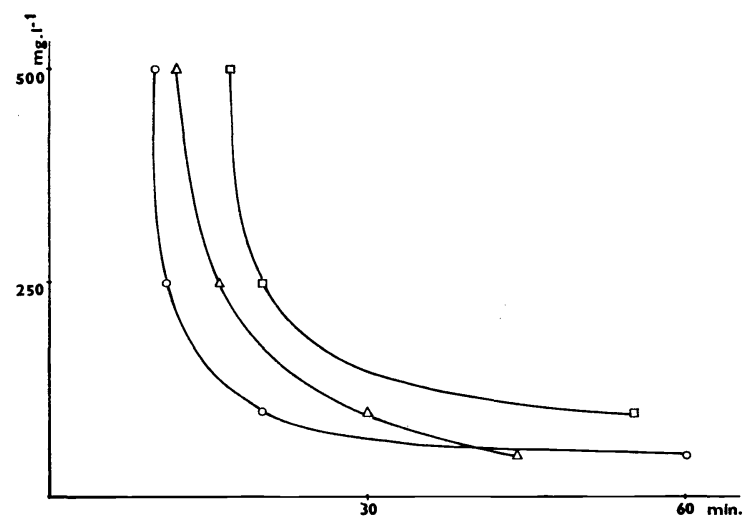

Fig. 2: Course of lethal intoxication by Elocron WP 50

Clinical findis: Extremely rapid course of intoxication is typical of Elocron WP 50. Upon exposure to high concentration, immediately loss of equilibrium occurred, followed by motor incoordination and movements in the upper part of the aquarium. Later recumbent or vertical position with head downards, occasional jumping above the water surface occurred. The most vigorous excitation was seen in the rainbow trout. In coma, the fish were lying on the bottom of the vessel with mouth and opercles wide-open and typical arch-like bending of the spine. In Poecilia reticulata invariably intensive colour of the body surface was noted. At lower concentrations of the toxic substance restlessness followed by loss of equilibrium occurred. All fish showed high excitability.

Pathoanatomical findings: Body surface of intoxicated fish was slightly more mucous. In the carp no changes in skin colour were seen, in the rainbow trout more intensive colours occurred except for the area of the breast fins being very pale. Single haemorrhagiae were found in the eyes. Slightly more mucus was also found on the gills and on the lower part of the opercles. The gills had smooth edges and normal colour. Injected blood vessels of hepatopancreas and liver were noted.

Furadan G-5

Toxicity for fish: The $\mathrm{LC}_{50}$ was $11.0 \mathrm{mg} .1^{-1}$ for the carp, $8.5 \mathrm{mg} .1^{-1}$ for the rainbow trout and $3.4 \mathrm{mg} .1^{-1}$ for Poecilia reticulata in 48 hours. The minimum lethal concentration $\left(\mathrm{LC}_{5}\right)$ was $5.8 \mathrm{mg} .1^{-1}$ for the carp, $2.9 \mathrm{mg} .1^{-1}$ for the trout and $2.0 \mathrm{mg} .1^{-1}$ for Poecilia reticulata (see Fig. 3). According to the $\mathrm{LC}_{50}$ values Furadan G-5 should be included among compounds highly toxic for fish. 
Clinical findings: In exposed fish increasing restlessness, vigorous swimming to the water surface and jumping, loss of equilibrium, incoordinated movements followed by abnormal postures and swimming on one side, coma and death. In the period between the loss of equilibrium and death no excitations were observed except for the rainbow trout showing numerous excitations. In Poecilia reticulata stretched operculums and arch-like bending of the spine was observed in coma and death. The course of poisoning was extremely rapid in all three fish species.

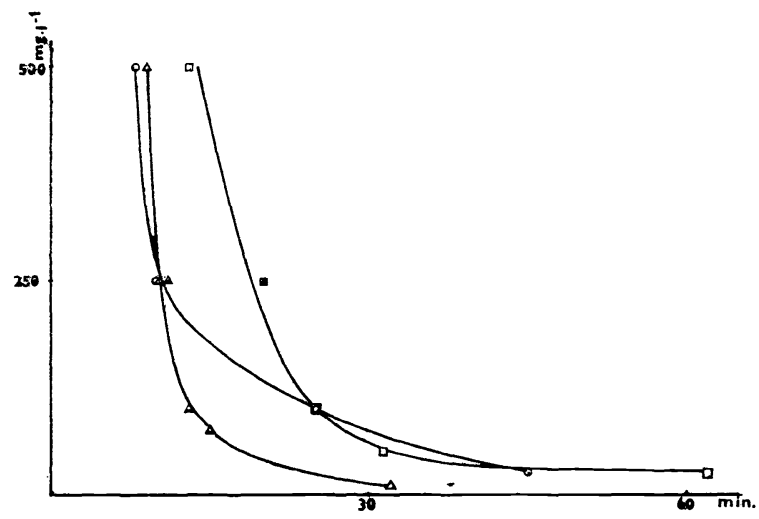

Fig. 3: Course of lethal intoxication by Furadan G-5

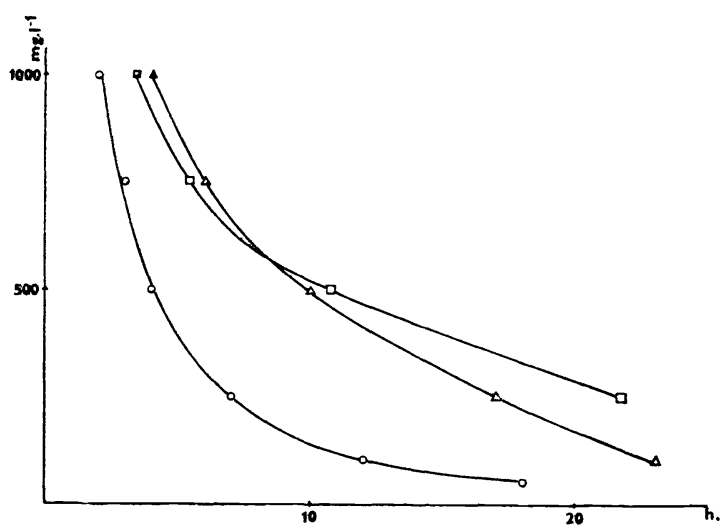

Fig. 4: Course of lethal intoxication by Fundazol

Pathoanatomical findings: Body surface was slightly more mucous. Local loss of pigmentation of the skin which became striped was a characteristic feature. The gills had smooth rims, and they were more mucous, of usual colour in the carp, congested in the trout. Haemorrhagiae were found in the eyes of the carp. Injected blood vessels of the liver and hepatopancreas were found.

\section{Fundazol}

Toxicity for fish: The $\mathrm{LC}_{50}$ of Fundazol was $190 \mathrm{mg} .1^{-1}$ for the carp, 1.8 $\mathrm{mg} .1^{-1}$ for the trout and $110 \mathrm{mg} \cdot 1^{-1}$ for Poecilia reticulata in 72 hours. The minimum lethal concentration $\left(\mathrm{LC}_{5}\right)$ was $76 \mathrm{mg} .1^{-1}$ for the carp, $0.49 \mathrm{mg} .1^{-1}$ 
for the rainbow trout and $65 \mathrm{mg} .1^{-1}$ for Poecilia reticulata. The course of poisoning may be seen from Fig. 4. According to the present results, Fundazol should be included among compounds highly toxic for fish.

Clinical findings: The poisoning was not as rapid as with other substances under study and the test was prolonged to 72 hours. Intoxication started with mild restlessness increasing with time. Later loss of equilibrium, motor incoordination, coma and death followed. In the entire course of poisoning depression prevailed in all fish.

Pathoanatomical findings: In necropsied carp and trout the skin was found to be more mucous; the skin was polluted and the gills slightly more mucous and also contaminated in fish exposed to higher concentrations of the compound. Their colour was unchanged in the carp but pale in the trout. Small haemorrhagiae were found in the eyes of the carp along with injected blood vessels of their hepatopancreas.

\section{Discussion}

The acute toxicity tests revealed the following order of toxicity for fish of the carbamate-based pesticides: Furadan G-5 $>$ Novozir MN $80>$ Elocron WP $50>$ Fundazol. All these compounds have been included among preparations highly toxic for fish on the basis of their $\mathrm{LC}_{5}$, values in 48 hours ( 72 hours for Fundazol). The $L_{50}$ values for Furadan G-5 and Novozir MN 80 were up to $10 \mathrm{mg} \cdot 1^{-1}$ for the rainbow trout and Poecilia reticulata, and $10-100 \mathrm{mg} \cdot 1^{-1}$ for the carp. Both preparations can be characterized as highly toxic for the two above-mentioned fish species, and toxic for the carp. Elocron WP 50 is highly poisonous for the rainbow trout and toxic for the carp and Poecilia reticulata. Fundazol was found to be highly toxic for the rainbow trout and moderately poisonous for the two remaining species having the $\mathrm{LC}_{\tilde{0} 0}$ above $100 \mathrm{mg} \cdot 1^{-1}$ (Table 1 ).

Table 1

Results of the acute toxicity tests with carbamate-based pesticides conducted in three fish species

\begin{tabular}{|c|c|c|c|c|c|c|c|c|}
\hline \multirow[t]{2}{*}{ Preparation } & \multirow[t]{2}{*}{$\begin{array}{c}\text { Concentration } \\
\text { of the active substance }\end{array}$} & & \multicolumn{2}{|c|}{$\begin{array}{l}\text { Carp } \\
\text { (Cyprinus } \\
\text { carpio L.) }\end{array}$} & \multicolumn{2}{|c|}{$\begin{array}{l}\text { Rainbow trout } \\
\text { (Salmo gaird- } \\
\text { neri Rich.) }\end{array}$} & \multicolumn{2}{|c|}{$\begin{array}{l}\text { Poecilia } \\
\text { reticulata P. }\end{array}$} \\
\hline & & & $L C_{s n}$ & LC $_{5}$ & $\mathrm{LC}_{50}$ & $\mathrm{LC}_{5}$ & $\mathrm{LC}_{50}$ & $\mathbf{L C}_{5}$ \\
\hline Novozir & mancozeb $-80 \%$ & $\mathrm{mg} \cdot 1^{-1}$ & 24 & 15 & 1.85 & 1.0 & 2.2 & 0.9 \\
\hline $\begin{array}{l}\text { Elocron } \\
\text { WP 50 }\end{array}$ & dioxacarb $-50 \%$ & $\mathrm{mg} \cdot 1^{-1}$ & 25.5 & 17.5 & 2.7 & 0.35 & 36 & 16 \\
\hline Furadan & carbofuran $-5 \%$ & $\mathrm{mg} \cdot 1^{-1}$ & 11 & 5.8 & 8.5 & 2.9 & 3.4 & 2.0 \\
\hline Fundazol & benomyl $-50 \%$ & $\mathrm{mg} \cdot 1^{-1}$ & 190 & 76 & 1.8 & 0.49 & 110 & 65 \\
\hline
\end{tabular}

Toxicity of pesticides based on various forms of carbamates for fish varies widely as indicated by earlier data (Williams et al. 1973; Svobodová and Fuka 1974; Wasserschadstoff-Katalog 1975) and by present results. It is likely that the anticholinesterase activity of various carbamates differs as is the case with the organic phosphorous compounds (Ševčík 1968; Riedl and Vondráček 1971). However, besides the concentration of the toxic compounds, also the possible poisonous effects of the secondary components (adjuvants, solvents), 
should be considered (Vejvoda 1966; Svobodová 1971; Kvasnička and Svobodová 1977).

The reported acute toxicity test showed the carbamate-based pesticides to be most toxic for the rainbow trout followed by Poecilia reticulata and the carp (Table 1). The widest differences in $\mathrm{LC}_{50}$ between the fish species under study were found for Fundazol being 60-100 times lower for the trout than for the carp and Poecilia reticulata. This difference can partly be ascribed to the fact that Fundazol with low solubility attached to the skin surface and gills of the fish so that besides its toxic effects it also interfered with the physiological function of the gills. This effect made itself felt especially in the rainbow trout, the species most vulnerable to oxygen defficiency as compared to the other two species.

The clinical findings in fish intoxicated with carbamate-based pesticides were similar for all tested preparations. Intoxication was characterized by increasing restlessness, rapid respiration, loss of equilibrium, motor incoordination, swimming on one side, coma and death. In fish poisoned with Furadan G-5 and Fundazol depression predominated. The course of poisoning was extremely rapid with Elocron WP 50 and Furadan G-5. The pathoanatomical findings showed no characteristic features.

It can be concluded that the clinical and pathoanatomical findings in fish intoxicated with carbamate-based pesticides do not provide typical symptoms serving for unequivocal diagnosis of the poisoning.

\section{Akutní toxicita pesticidů na bázi karbamátů pro ryby}

Podle ČSN 466807 Test akutní toxicity na rybách bylo provedeno ichtyotoxikologické posouzení pesticidů na bázi karbamátů. Testovány byly př́ípravky Novozir MN 80, Elocron WP 50, Furadan G-5 a Fundazol. Na základě zjištěných hodnot $\mathrm{LC}_{50}$ byly všechny testované př́ípravky zařazeny do skupiny látek pro ryby silně jedovatých. Podle stupně toxicity lze jednotlivé preparáty uvést v následujícím pořadí: Furadan G-5 $>$ Novozir $M N 80>$ Elocron WP $50>$ Fundazol. Podle vnímavosti $\mathrm{k}$ pesticidům na bázi karbamátů je možno jednotlivé druhy ryb seřadit tímto zpưsobem: pstruh duhový $>$ Poecilia reticulata $>$ kapr obecný. Popsaný klinický a patoanatomický obraz intoxikace ryb pesticidy na bázi karbamátů není specifický.

\section{Острая токсичность пестицидов на основе карбаматов для рыб}

Соответственно ЧСН 466807 Тест острой токсичности на рыбах проводилась ихтиологическая оценка пестицидов на основе карбаматов. Проверялись препараты Новозир МН 80, Элокрон ВП 50, Фурадан Г-5 и Фундазол. На основе выявленных величин ЛС50 все проведяемые препараты были включены в группу вещества, отличающихся сильной ядовитостью для рыб. По степени токсичности возможно вешества привести в следующем порядке: Фурадан $Г$ 5 $>$ Новозир МН $80>$ Элокрон ВП $50>$ Фундазол. По восприимчивости к пестицидам на базе карбаматов отдельные виды рыб можно привести в следующем порядке: форель пеструшка $>$ Eoecilia reticulata $>$ карп. Описанная клиническая и патоанатомическая картина интоксикации рыб пестицидами на основе карбаматов не является специфической. 


\section{References}

ČSN 466807 - Test akutní toxicity na rybách. 1975, 7 pp.

Připravky na ochranu rostlin. Soubor návodů $\mathrm{k}$ použití povolených přípravků na uchranu rostlin. SZN Praha, 1978.

Wasserschadstoff-Katalog, Institut für Wasserwirtschaft, Berlin, 1975.

KVASNIČKA, P. - SVOBODOVÁ, Z.: Toxicita kombinovaných herbicidů s obsahem MCPA pro ryby. Agrochémia, 17, 1977: 65-68.

RIEDL, O. - VONDRÁČEK, V.: Klinická toxikologie. Avicenum, Praha 1971, 679 pp.

SVOBODOVÁ, Z.: Toxicita pesticidů s obsahem kyseliny fenoxyoctové pro ryby. Buletin VÚRH Vodňany, 7, 1971: 24-33.

SVOBODOVÁ, Z. - FUKA, T.: Akutní toxicita Pirimoru pro ryby. Veterinářství, 24, 1974:503

SVOBODOVÁ, Z. - KOCOVÁ, A.: Diagnostika intoxikací ryb ve Výzkumném ústavu rybářském a hydrobiologickém ve Vodňanech v letech 1967-1972. Buletin VÚRH Vodňany, 9, 1973: $24-28$.

ŠEVČíK, M.: Praktická toxikologie. SZdN Praha, 1968. 350 pp.

VEJVODA, M.: Toxické působení herbicidů na ryby. Agrochémia, 6, 1966: 251-253.

WILLIAMS, B. R. H. - BULLOCK, D. J. W. - MARRS, G. J.: Pirimicarb: Toxicity to rainbow trout (Salmo gairdneri) and to common carp (Cyprinus carpio). (C), Plant Protection Ltd., G. Britain, 1973, Report Series TMF 901 A, 11 pp. 